\title{
Review Article Experimentally Induced Mammalian Models of Glaucoma
}

\author{
Makoto Ishikawa, ${ }^{1}$ Takeshi Yoshitomi, ${ }^{1}$ Charles F. Zorumski, ${ }^{2,3}$ and Yukitoshi Izumi ${ }^{2,3}$ \\ ${ }^{1}$ Department of Ophthalmology, Akita Graduate University School of Medicine, 1-1-1 Hondo, Akita 010-8543, Japan \\ ${ }^{2}$ Department of Psychiatry, Washington University School of Medicine, St. Louis, MO 63110, USA \\ ${ }^{3}$ The Taylor Family Institute for Innovative Psychiatric Research, Washington University School of Medicine, St. Louis, MO, USA \\ Correspondence should be addressed to Makoto Ishikawa; mako@med.akita-u.ac.jp
}

Received 25 September 2014; Accepted 1 December 2014

Academic Editor: Oreste Gualillo

Copyright (c) 2015 Makoto Ishikawa et al. This is an open access article distributed under the Creative Commons Attribution License, which permits unrestricted use, distribution, and reproduction in any medium, provided the original work is properly cited.

\begin{abstract}
A wide variety of animal models have been used to study glaucoma. Although these models provide valuable information about the disease, there is still no ideal model for studying glaucoma due to its complex pathogenesis. Animal models for glaucoma are pivotal for clarifying glaucoma etiology and for developing novel therapeutic strategies to halt disease progression. In this review paper, we summarize some of the major findings obtained in various glaucoma models and examine the strengths and limitations of these models.
\end{abstract}

\section{Introduction}

Glaucoma is characterized by progressive and accelerated loss of retinal ganglion cells (RGCs) and their axons [1]. Although the pathogenesis of glaucoma is not fully understood, it is believed that increased intraocular pressure (IOP) is a major contributor even in normal tension glaucoma [2]. In this context, a wide variety of animal models have been developed to study the effect of elevated IOP on the optic nerve and the RGC degeneration.

In general, animal glaucoma models are classified into two categories: natural-occurring models and induced models. A variety of natural-occurring glaucoma models have been described in different animal species including dog (beagle) [3], albino New Zealand rabbit [4], and DBA/2J mice [5-7]. It has been considered that the disturbance or obstruction of aqueous outflow could be the cause of IOP elevation, which induces a loss of RGCs and excavation of the optic nerve in these models [8]. Because naturally occurring glaucoma models are poor in controlling onset and pathological course of the disease, induced glaucoma models have been developed with the aim to create proper conditions for controlled experiments. The earliest models of induced glaucoma were developed in monkeys [9], and IOP elevation was induced by intraocular $\alpha$-chymotrypsin injections [10]. Thereafter, multiple in vivo glaucoma models have been developed using laser photocoagulation of the perilimbal region [11], autologous fixed red blood cell (RBC) injection [12] or microbead injection into the anterior chamber [9], cauterization of episcleral veins [13], or hypertonic saline injection into the episcleral veins $[14,15]$. Recently, in vitro [16] and ex vivo glaucoma models [17] have been developed to improve the accuracy and repeatability of experimental conditions and to examine pathological mechanisms especially in the acute phase of the IOP elevation. Hydrostatic pressure is applied to cells cultured on a rigid substrate or to isolated retinal tissues in vitro and ex vivo. More recently, transgenic mouse glaucoma models, which were genetically modified by the introduction of a foreign DNA sequence into a mouse egg, have emerged [18].

In this paper, we present a summary of experimentally induced mammalian glaucoma models that have been developed and used for the recent study of the different types of glaucoma and discuss limitations and potential use of each model.

\section{In Vivo Glaucoma Models}

2.1. Laser Photocoagulation of the Perilimbal Region. Multiple studies have used laser photocoagulation which induced sustained IOP elevation in monkeys [11], mice [19, 20], rats [21], and rabbits [22-24]. These models were primarily 
developed to study retinal IOP-related posterior segment damage. The IOP elevations in eyes treated with laser photocoagulation are thought to result from increased resistance of outflow pathways such as angle closure, trabecular scarring, and obliteration of Schlemm's canal [11]. Gaasterland and Kupfer (1974) [11] applied repeated, circumferential argon laser photocoagulation to the trabecular meshwork in both eyes of each of the five Rhesus monkeys and induced a sustained IOP elevation in seven out of ten eyes by a marked reduction in outflow. The IOP range was between 24 and $50 \mathrm{~mm} \mathrm{Hg}$ after the 4th treatment and remained elevated by 30 days. The main outcome analyzed to determine whether this experimental ocular hypertension can induce a glaucoma was indicated by the observed development of cupping of the optic disc and by the selective loss of retinal ganglion cells in histopathologic specimens. This model became the standard for laser-induced glaucoma in monkeys [25-29].

The advantage of the primate model is that the monkeys have eyes with similar anatomical characteristics to humans. Although monkeys are excellent animal models for studying human disease, there are several limitations to use monkeys, including ethical and economic factors [30, 31]. Laser photocoagulation requires expensive ophthalmic equipment and highly specialized techniques. Laser photocoagulation sometimes induces the inflammation of the anterior chamber and irreversible mydriasis [28].

In contrast to primate models, there are several advantages of using rodents (mice, rats, and rabbits) in glaucoma research. Rodents are inexpensive and easy to house and handle, their eyes are easy to obtain, and the sample number for studies can be large [32]. Aihara et al. (2003) [19] applied argon laser photocoagulation to the corneal limbus in Black Swiss mice after flattening the anterior chamber by aspiration of aqueous humor and successfully induced persistent elevation of IOP for at least 6 weeks in mouse eyes. The flattening of the anterior chamber appears to bring the trabecular meshwork into closer proximity to limbal areas targeted with the laser and may be useful in enhancing the effect of photocoagulation to obstruct the anterior chamber angle [19]. Significant increases in mean IOP during 4 to 12 weeks were detected in treated eyes [19]. Average IOPs in laser-treated eyes (IOPtx) versus contralateral control eyes (IOPc) during the first 4 weeks and during the entire 12-week study period were $23.4 \pm 5.1 \mathrm{~mm} \mathrm{Hg}$ versus $16.3 \pm 2.3 \mathrm{~mm} \mathrm{Hg}$ and $20.1 \pm 3.5 \mathrm{~mm} \mathrm{Hg}$ versus $16.2 \pm 2.4 \mathrm{~mm} \mathrm{Hg}$, respectively [19]. Average IOPtx was significantly higher than the average IOPc during both periods $(P<0.001)$ [19]. A treatment response was considered to be a success if either the mean of IOP measurements collected during the first 4 weeks was increased by $30 \%$ or more or the mean of all measurements collected during the 12-week study period was increased by $30 \%$ or more [19]. During the first 4 weeks, 14 (64\%) of 22 eyes had an IOP increase of more than 30\% [19]. During the entire 12 -week study, 7 (37\%) of 19 eyes maintained an IOP increase of greater than $30 \%$ [19]. The success rate of IOP elevation after a single procedure is relatively high compared with other glaucoma models. Histologic analysis at the end of the 12-week study showed that the angle was completely closed by the laser photocoagulation treatment
[20]. Disadvantages of this method include ocular inflammation induced by laser treatment, flattening of the anterior chamber, and variability of IOP magnitude and duration [19]. In addition, the IOP elevation was not sustained in the treated eyes, slowly declining to baseline by 8 weeks after treatment [19]. In optic nerve cross sections examined by electron microscopy $300 \mu \mathrm{m}$ posterior to the globe [20], mean axon density and total number of axons in the laser treated eyes were significantly decreased compared with the control eyes.

Other studies applying argon laser photocoagulation to the episcleral and limbal veins in $\mathrm{C} 57 \mathrm{BL} / 6$ mice $[33,34]$ induced IOP elevations lasting for weeks after treatment, with decline to baseline levels approximately 8 weeks after treatment [34]. After laser treatment, mean IOP was increased in the treated eyes from the control mean of $13 \pm 1.8 \mathrm{~mm} \mathrm{Hg}$ to $20.0 \pm 2.8 \mathrm{~mm} \mathrm{Hg}$ at 4 weeks in C57BL/6 mice [33]. Peak IOP was $32 \pm 2.5 \mathrm{~mm} \mathrm{Hg}$ in the experimental group. RGC loss was $16.9 \% \pm 7.8 \%$ at 2 weeks $(P<0.05)$ and $22.4 \% \pm$ $7.5 \%$ at 4 weeks $(P<0.05)$ after laser photocoagulation [33]. TUNEL staining showed that there were marked increases in the number of apoptotic nuclei in the ganglion cell layer in the treated eyes [33]. Laser photocoagulation of limbal and episcleral veins also induces transient ocular hypertension in albino CD-1 mice [35]. In albino CD-1 mice, the IOPs measured in operative eyes $(27.6 \pm 2.6 \mathrm{~mm} \mathrm{Hg})$ were significantly elevated above those measured in control eyes $(12.3 \pm 1.0 \mathrm{~mm} \mathrm{Hg}) 4$ hours after laser treatment and remained elevated at the second postoperative day (operative $27.1 \pm 1.8 \mathrm{~mm} \mathrm{Hg}$ versus control $13.4 \pm 0.3 \mathrm{~mm} \mathrm{Hg}$ ) [35]. IOPs measured in laser-treated eyes declined to baseline and were similar to IOPs in control eyes by 1 week (operative $15.4 \pm$ $1.3 \mathrm{~mm} \mathrm{Hg}$ versus $12.4 \pm 0.6 \mathrm{~mm} \mathrm{Hg}$ ). Overall, the elevation of IOP is transient in these laser models, and the level of cell loss is modest.

Similar to mice, rats are easy to maintain in the laboratory, and they can be used in large numbers [21,36-40]. Laser photocoagulation has been applied to the trabecular meshwork alone [41] or the trabecular meshwork and episcleral veins [42] in rats, and the induced IOP elevation results in subsequent glaucomatous damage, including RGC loss [41, 42]. Levkovitch-Verbin et al. [42] induced experimental glaucoma unilaterally in Wistar rats, using a diode laser with wavelength of $532 \mathrm{~nm}$ aimed only at the trabecular meshwork (trabecular group) or at episcleral veins (combination treatment group) through the external limbus. IOP was increased in all eyes to higher than the normal mean IOP of $19.4 \pm$ $2.1 \mathrm{~mm} \mathrm{Hg}$ after the laser treatment [42]. Peak IOP was $34.0 \pm$ $5.7 \mathrm{~mm} \mathrm{Hg}$ in the trabecular group and $49.0 \pm 6.1 \mathrm{~mm} \mathrm{Hg}$ in the combination group [42]. Mean IOP after 6 weeks was $22.0 \pm 1.8 \mathrm{~mm} \mathrm{Hg}$ in glaucomatous eyes in the trabecular group compared with $25.5 \pm 2.9 \mathrm{~mm} \mathrm{Hg}$ in the combination group [42]. IOP in the glaucomatous eyes was typically higher than in the control eyes for at least 3 weeks [42]. In the combination group, RGC loss was $16.1 \% \pm 14.4 \%$ at 1 week $(P<0.01), 59.7 \% \pm 25.7 \%$ at 6 weeks $(P<0.001)$, and $70.9 \% \pm 23.6 \%$ at 9 weeks $(P<0.001)$ [42]. The trabecular group had mean axonal loss of $19.1 \% \pm 14.0 \%$ at 3 weeks $(P<0.004)$ and $24.3 \% \pm 20.2 \%$ at 6 weeks $(P<0.001)[42]$. Laser treatment led to closure of intertrabecular spaces and 
the major outflow channel [42]. The retina and choroid were normal by ophthalmoscopy at all times after treatment. Light microscopic examination showed only loss of RGCs and their nerve fibers [42]. Although continuous IOP elevation over longer periods is ideal, 3 weeks of elevated IOP induces substantial RGC loss and axonal damage of the optic nerve, making the model attractive for most investigations [42].

There are several limitations to using laser-induced ocular hypertension in rats. First, differences in pigmentation of the trabecular meshwork markedly change the effects of laser photocoagulation to increase IOP. Second, repeated laser treatments induce ocular inflammation and corneal opacity [43].

2.2. Red Blood Cell or Microbead Injections into the Anterior Chamber. To circumvent the limitations and disadvantages of laser techniques, microbeads were injected into the anterior chamber to induce ocular hypertension in primates [9], pigs [30], mice [44], rats [45], and rabbits [46]. An alternative to microbead injection uses injection of autologous fixed red blood cells (RBCs) into the anterior chamber [12, 47]. Elevations in IOP observed in autologous RBCs- or microbeadinjected eyes are thought to result from inhibition of aqueous outflow.

Experimental primate models of chronic IOP elevation were developed by Quigley and Addicks (1980) using autologous fixed RBCs (ghost cells) [12, 47]. Direct obstruction of the trabecular meshwork by ghost cells as well as swelling of trabecular cells following phagocytosis of cellular debris was observed by electron microscopy. The model has the advantages of producing IOP elevation easily (mean IOP, $24 \mathrm{~mm} \mathrm{Hg}$ to $73 \mathrm{~mm} \mathrm{Hg}$ ) and without associated intraocular inflammation [12]. However, IOP elevations lasted from 2 to 42 days, and the extensive filling of the anterior chamber with ghost cells resulted in poor visibility of the optic disk [12]. Ghost cells are degenerating red blood cells without hemoglobin content. Subsequently, Weber and Zelenak (2001) [48] reported that multiple injections of sterile latex microspheres $\left(2-4 \times 10^{5}\right.$ sterile beads per injection) into the primate anterior chamber are simple and cost effective for inducing chronic IOP elevation [48]. In the treated eyes with multiple injections of latex microspheres, mean IOP was $17.8 \mathrm{~mm} \mathrm{Hg}$ to $36.7 \mathrm{~mm} \mathrm{Hg}$, and peak IOP was $23 \mathrm{~mm} \mathrm{Hg}$ to $65 \mathrm{~mm} \mathrm{Hg}$ [48]. Different levels and durations of elevated IOP can be obtained by altering the frequency and number of microspheres injected [47]. This approach has the advantages of producing IOP elevations while preserving visibility of the optic disc, which is necessary for assessment of glaucoma development [48]. Fluorescent polystyrene microbead injection into the anterior chamber of $\mathrm{C} 57 \mathrm{BL} / 6$ mice results in chronic IOP elevation $(4.6 \pm 0.6 \mathrm{~mm} \mathrm{Hg}$ above control IOP) lasting for at least 3 weeks following a single injection [49]. Cone et al. (2012) [50] maintained the IOP elevation by a combination of polystyrene bead injection followed by viscoelastic solution injection into the mouse anterior chamber. The disadvantages of the mouse model include the relatively small size of the globe, which makes it hard to manipulate.
IOP elevations induced by microbeads have also been described in rat models [40]. In Wistar rats injected with microbeads, IOP elevation persists for two weeks and results in reduced density of the optic nerves $[40,51]$. Wistar rats receiving weekly injections of hyaluronic acid show IOP elevation that persists for at least 10 weeks [51].

Taken together, microbead injection models offer a relatively easy technique without special equipment, and the IOP elevation can be modulated with subsequent injections of microbeads or viscous materials. The principal disadvantage is that microbeads can be difficult to retain in the anterior chamber angle after injection. To address these issues, Samsel et al. (2011) [52] developed a technique for induction of ocular hypertension using paramagnetic microbeads. Magnet is used to direct microbead to the anterior chamber angle. These beads have the advantage that they can be directed to the anterior chamber angle in the rodent eye to optimize occlusion of the trabecular meshwork. In this case, the paramagnetic microbeads could be directed to the iridocorneal angle using a handheld magnet [52].

2.3. Episcleral Vein Obstruction. Shareef et al. (1995) [15] developed an episcleral vein cauterization model of glaucoma in rat. This method is less invasive than laser photocoagulation and induces no complications in the anterior chamber [53]. Because of its efficacy and accessibility, the majority of the structural and functional studies in experimental glaucoma have used this method [13]. IOP elevations in this model are thought to involve increased outflow resistance [54].

Mouse glaucoma models induced by episcleral vein cauterization exhibit significantly elevated IOP $(28 \pm 1.5 \mathrm{~mm} \mathrm{Hg})$ for up to 4 weeks and loss of RGCs [54]. Photocoagulation of episcleral and limbal veins induces a doubling of IOP lasting for 4 hours in albino CD1 mice $[55,56]$. Complications of episcleral vein cautery in mice include thermal damage to sclera, intraocular inflammation, and ocular surface damage.

To compare the effects of IOP elevation on ganglion cell size and death, Vecino and Sharma (2013) [57] used three experimental glaucoma models in rats: (i) injections of latex microspheres into the anterior chamber, (ii) injections of microspheres and hydroxypropylmethylcellulose into the anterior chamber, and (iii) cauterization of three episcleral veins. IOP elevation induced by episcleral vein coagulation was more stable and constant for at least 24 weeks as compared with the other two experimental glaucoma methods. Similar results were observed when the three methods were compared in rats [58] and pigs [44].

Morrison et al. [14] have suggested, however, that pathophysiology in the episcleral vein cautery model differs from the other two ocular hypertension models, and the pattern of RGC death might be different in this model. While axonal degeneration of RGCs is the predominant finding in the other IOP elevation models, episcleral vein cautery appears to produce general RGC loss, indicating the possibility that factors other than IOP elevation might contribute to RGC death in episcleral vein cautery models. 
TABLE 1: Experimentally induced in vivo mammalian glaucoma models.

\begin{tabular}{|c|c|c|c|c|c|}
\hline $\begin{array}{l}\text { In vivo glaucoma } \\
\text { models }\end{array}$ & Species & Main papers & $\begin{array}{c}\text { Main outcomes } \\
\text { measured }\end{array}$ & Cost & Limitation \\
\hline \multirow{3}{*}{$\begin{array}{l}\text { Laser } \\
\text { photocoagulation of } \\
\text { the perilimbal region }\end{array}$} & Monkey & Gaasterland and Kupfer (1974) [11] & $\begin{array}{l}\text { IOP, cupping, HR, } \\
\text { HI, OF }\end{array}$ & \multirow{3}{*}{$\begin{array}{l}\text { Expensive } \\
\text { (laser } \\
\text { equipment) }\end{array}$} & $\begin{array}{l}\text { Ocular inflammation } \\
\text { Irreversible mydriasis } \\
\text { Technical difficulties }\end{array}$ \\
\hline & Mouse & $\begin{array}{l}\text { Aihara et al. (2003) [19] } \\
\text { Mabuchi et al. (2003) [20] }\end{array}$ & $\begin{array}{c}\text { IOP } \\
\text { IOP, HR }\end{array}$ & & $\begin{array}{l}\text { Ocular inflammation } \\
\text { Variability of IOP } \\
\text { Technical difficulties }\end{array}$ \\
\hline & Rat & $\begin{array}{l}\text { Levkovitch-Verbin et al. (2002) } \\
{[42]}\end{array}$ & IOP, HR, HI & & $\begin{array}{l}\text { Hyphema, corneal opacity } \\
\text { Ocular inflammation }\end{array}$ \\
\hline $\begin{array}{l}\text { RBC injections into } \\
\text { the anterior chamber }\end{array}$ & Monkey & $\begin{array}{l}\text { Quigley and Addicks (1980) } \\
{[12,47]}\end{array}$ & IOP, HR, HI, OF & \multirow{3}{*}{$\begin{array}{l}\text { Not } \\
\text { expensive }\end{array}$} & \multirow{3}{*}{$\begin{array}{l}\text { Low visibility of optic discs by } \\
\text { accumulation of RBC or } \\
\text { microbeads }\end{array}$} \\
\hline $\begin{array}{l}\text { Microbead injections } \\
\text { into the anterior } \\
\text { chamber }\end{array}$ & $\begin{array}{l}\text { Rat } \\
\text { Mouse }\end{array}$ & $\begin{array}{l}\text { Weber and Zelenak (2001) [48] } \\
\text { Pang et al. (2005) [40] } \\
\text { Sappington et al. (2010) [49] }\end{array}$ & $\begin{array}{l}\text { IOP, HR, HI } \\
\quad \text { IOP } \\
\text { IOP, HR, HI }\end{array}$ & & \\
\hline $\begin{array}{l}\text { Hyaluronic acid } \\
\text { injection into the } \\
\text { anterior chamber }\end{array}$ & Rat & Moreno et al. (2005) [51] & IOP, HR, HI, ERG & & \\
\hline \multirow{2}{*}{$\begin{array}{l}\text { Episcleral vein } \\
\text { obstruction }\end{array}$} & Rat & Shareef et al. (1995) [15] & IOP & \multirow{2}{*}{$\begin{array}{l}\text { Not } \\
\text { expensive }\end{array}$} & \multirow{2}{*}{$\begin{array}{l}\text { Scleral thermal burns (RGC death } \\
\text { patterns may be different from } \\
\text { those of other glaucoma models) }\end{array}$} \\
\hline & Mouse & $\begin{array}{l}\text { Ruiz-Ederra and Verkman (2006) } \\
\text { [54] }\end{array}$ & IOP, HR, OF & & \\
\hline $\begin{array}{l}\text { Episcleral vein saline } \\
\text { injection }\end{array}$ & $\begin{array}{l}\text { Rat } \\
\text { Mouse }\end{array}$ & $\begin{array}{l}\text { Morrison et al. (1997) [14] } \\
\text { Kipfer-Kauer et al. (2010) [59] }\end{array}$ & $\begin{array}{l}\text { IOP, HR, HI } \\
\text { IOP, HR }\end{array}$ & $\begin{array}{l}\text { Not } \\
\text { expensive }\end{array}$ & Technical difficulties \\
\hline
\end{tabular}

IOP: IOP measurement, cupping: assessment of optic disc cupping, HR: histological assessment of retinal nerve fibers and optic discs, HI: histological assessment of the iridocorneal angles, OF: outflow facility, ERG: electroretinography.

2.4. Episcleral Vein Saline Injection. Kipfer-Kauer et al. (2010) [59] have succeeded in inducing chronic IOP elevation in C57BL/6 mice by injection of $1.5 \mathrm{M}$ hypertonic saline into a limbal vein. The hypertonic saline injection group revealed a mean IOP of $9.99 \pm 3.3 \mathrm{~mm} \mathrm{Hg}$ versus $7.42 \pm 2.2 \mathrm{~mm} \mathrm{Hg}$ in the contralateral control eye. Peak IOP in the hypertonic saline injection group was $15.6 \mathrm{~mm} \mathrm{Hg}$ versus $11.6 \mathrm{~mm} \mathrm{Hg}$ in the control group. Episcleral vein saline injection causes an increase in the resistance of aqueous outflow channels. To develop chronically elevated IOP in rats, episcleral veins were injected with hypertonic saline in Brown Norway rats, and IOP elevations ( 7 to $28 \mathrm{~mm} \mathrm{Hg}$ above control pressure) were sustained after 4 weeks [14]. The anterior chamber angles showed the formation of the peripheral anterior synechia. Electron micrographs of eyes from this model showed glaucomatous damage of RGC axons [14].

The disadvantage of these latter models is the relative difficulty of the induction technique. Insertion of a microneedle into the rat episcleral vein requires considerable training and experience. An additional disadvantage is that the duration of IOP elevation is relatively short and sequential hypertonic saline injections are needed to produce longer lasting IOP changes [60].

Taken together, a wide variety of in vivo animal models have been developed to study the effect of elevated IOP on the optic nerve and RGC degeneration. However, the duration of IOP elevation in these models is transient without sequential treatments. In addition, precise control over IOP elevation is difficult, and the timing of induction and progression of glaucoma are usually unpredictable. Table 1 is the summarization of characteristics of the experimentally induced in vivo mammalian glaucoma models.

\section{In Vitro Glaucoma Models}

While in vivo animal models are necessary to show that a phenomenon occurs in living organisms, experiments in live animals typically involve undefined and uncontrollable factors [43]. Therefore, in vitro experimental systems are useful for producing highly controlled experimental conditions to manipulate specific variables contributing to degenerative changes [43]. Recently, in vitro glaucoma models that use cells cultured on a rigid substrate have been described [16, 61-72]. These models have used RGCs, optic nerve head astrocytes, or other types of retinal cells and sometimes have been equipped with pressure loading systems.

The application of hydrostatic pressure induces remarkable changes including enhancement of RGC apoptosis [64, 66], alterations in astrocyte structure [57], cell migration [63], elastin synthesis [68], and production of neural cell adhesion molecules [69]. Obazawa et al. (2004) [73] developed a cell culture system for manipulating hydrostatic pressure to examine the expression of optineurin and myocilin genes in trabecular meshwork cells under normal and hyperbaric 


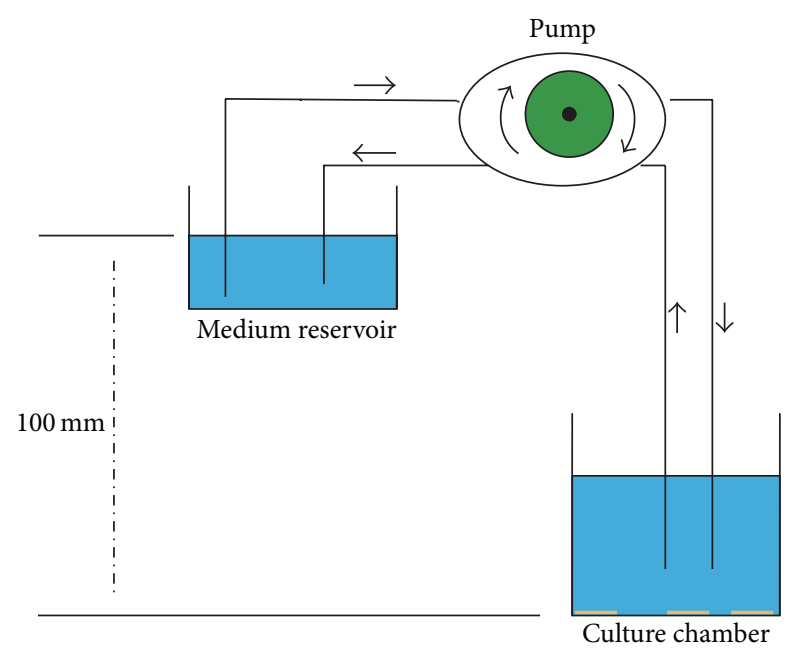

FIGURE 1: System used for hydrostatic pressure experiments. The culture chamber was filled with medium. The height of the medium reservoir was adjusted to maintain the pressure in the culture. For gas exchange, the medium was circulated by a peristaltic pump, and the pressure was monitored with the pressure gauge. This figure is the modification of Figure 1 of Lei et al. [61] and Figure 1 of Obazawa et al. [73].

conditions (Figure 1). Kashiwagi et al. (2004) [74] examined the survival and morphology of isolated RGCs subjected to centrifugal force loading using the unique device (Figure 2). The device includes a rotating vessel installed within a large incubator (model CPO2-1800; Hirasawa, Tokyo, Japan), a power supply unit, a control unit, and a cooling motor for removing heat generated by the motor installed outside the device. The rotor spins at 1 to 30 rotations per minute $(\mathrm{rpm})$, with a rotation accuracy of $0.01 \mathrm{rpm}$. The equation for calculating centrifugal force $(F)$ is $F(\mathrm{~mm} \mathrm{Hg}) \fallingdotseq 1.12 r \times$ $(\mathrm{rpm} / 1000) \times 750$, where $r$ is radial distance (in millimeters).

Recently, Yu et al. (2011) [75] developed a more convenient and simple pressure system using T75 culture flasks. An air mixture of $95 \%$ air and $5 \% \mathrm{CO}_{2}$ is pumped into the flasks to obtain the desired pressure.

In vitro models are also useful for investigating the role of apoptotic mechanism in RGCs. RGC death induced by IOP elevation involves caspase activation as demonstrated using experimental rat models of glaucoma [76]. In vitro studies provide strong evidence that apoptosis of retinal neurons induced by different stimuli shares a common caspase cascade $[66,77]$, which can be inhibited using specific caspase inhibitors [78]. Additionally, Tezel and Yang (2004) [79] applied TNF- $\alpha$ or hypoxia to primary cultures of rat RGCs for up to 48 hours and found that inhibition of caspases cannot block RGC death if the mitochondrial membrane potential is lost and cell death mediators (cytochrome $\mathrm{c}$ and apoptosis-inducing factor) are released.

Identification of precise cellular mechanisms in glaucoma requires isolation and primary culture of the RGCs. It has been known that in vitro experiments using primary cultures of RGCs are difficult to perform, mainly because of the limited yield and the typically postmitotic features of these

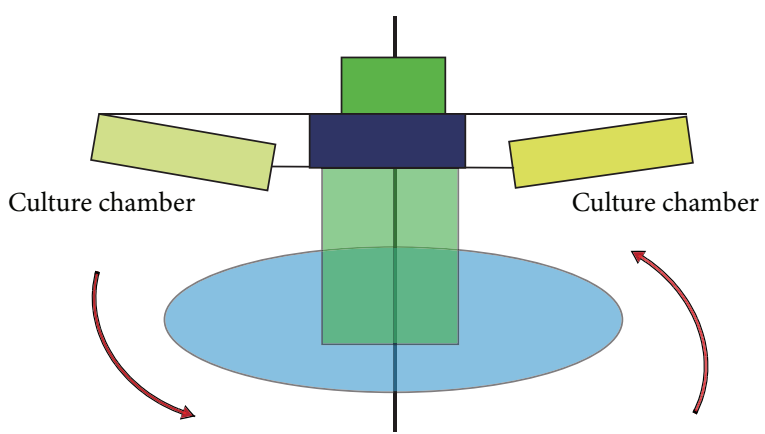

FIGURE 2: Schema of the centrifugal force loading device. The device is composed of two culture chambers and a motor unit for providing centrifugal force and rotor vessels. The isolated cells are situated at the bottom of the culture dish to become perpendicular to the direction of the centrifugal force and gravity vectors corresponding to a rotation speed. This figure is the modification of Figure 1 of Kashiwagi et al. [74].

neurons [80]. Therefore, early postnatal tissues are used in an attempt to optimize cell number and survival in culture. However, there are differences in cell responses between postnatal and adult cells that can limit interpretation of experimental results. In addition, it is difficult to examine interactions between RGCs and other types of cells such as retinal glia in specific mechanisms.

\section{Ex Vivo Glaucoma Models}

We recently developed a new ex vivo experimental model for acute glaucoma that involves incubating rat retinal segments under hydrostatic pressure at the bottom of a deep cylinder [17] (Figure 3). Acute high pressures can induce retinal ischemia clinically and in in vivo glaucoma models $[81,82]$. The ex vivo hydrostatic pressure model excludes the influence of ischemia and can thus allow examination of the direct effects of hydrostatic pressure on the otherwise intact retina, including changes in gene and protein expression $[83,84]$.

While the ex vivo system produces reliable results, we note several limitations. Survival factors for retinal neurons supplied from the blood stream or axonal transport are eliminated in ex vivo preparations, and the incubation period is limited by the duration in which the tissue can be kept alive. The advantages of this model include a higher degree of control over experimental variables and better preservation of neuron-neuron and neuron-glial interactions that are possible in dissociated cell preparations.

Of interest in this ex vivo model is the finding that axonal swelling in RGCs is induced in a pressure-dependent manner. In the central nervous system, activation of neuronal glutamate receptors induces swelling of cell bodies and dendrites [85-88] and also produces $\mathrm{Na}^{+}$-dependent blebs in acutely isolated hippocampal neurons [89]. This swelling is caused by the influx of $\mathrm{Na}^{+}$and $\mathrm{Ca}^{2+}$ and the passive redistribution of chloride and water across neuronal membranes [88-90]. Similar events occurring in axons could contribute to the findings observed in the ex vivo glaucoma model. Because 


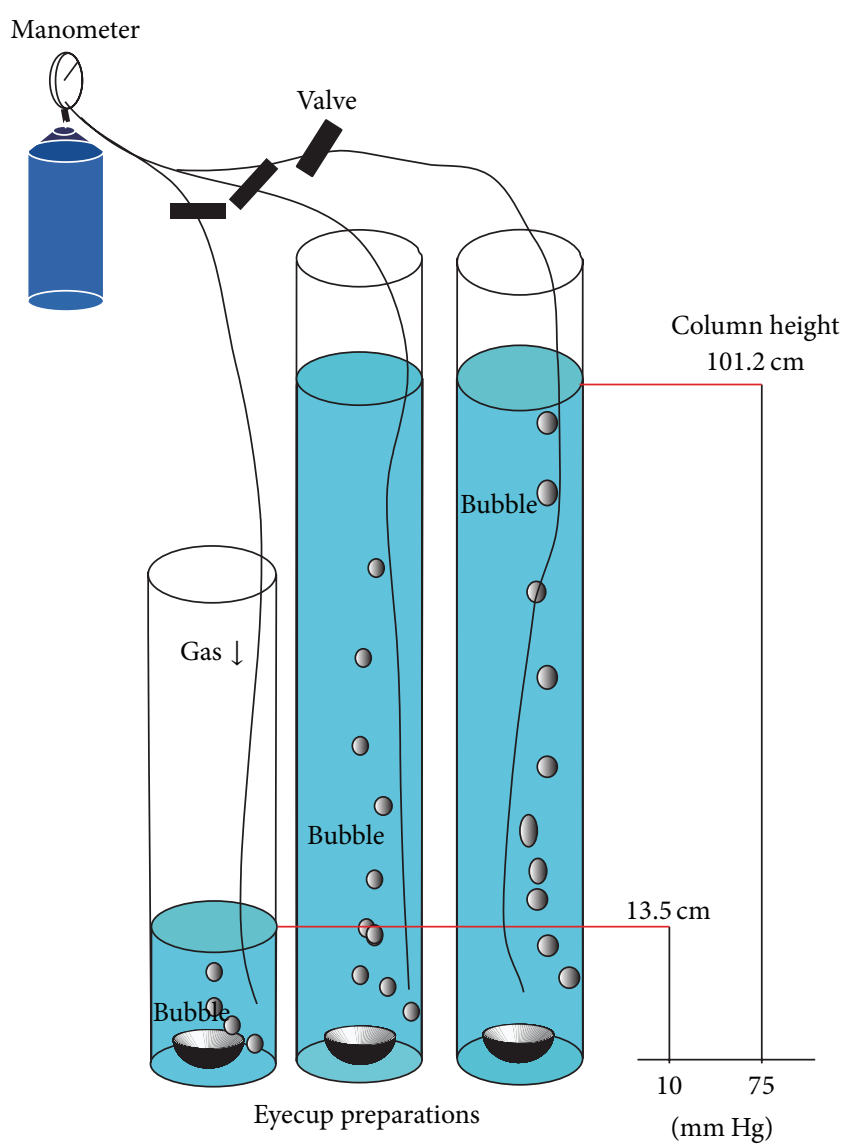

FIgURE 3: Outline of the experiment using ex vivo glaucoma model. Eyecups preparations were sunken to the bottom of a glass cylinder with different heights. Each cylinder was filled with incubation buffer at $30^{\circ} \mathrm{C}$ for 24 hours. The buffer was bubbled with $95 \% \mathrm{O}_{2}$ $5 \% \mathrm{CO}_{2}$. Hydrostatic pressure at the bottom of the cylinder was calculated to be $10 \mathrm{~mm} \mathrm{Hg}$ and $75 \mathrm{~mm} \mathrm{Hg}$ when a CSF was added to a height of $13.5 \mathrm{~cm}$ and $101.2 \mathrm{~cm}$, respectively. This figure is the modification of Figure 1 of Ishikawa et al. [17].

administration of glutamate receptor antagonists attenuated the axonal swelling, we hypothesize that glutamate-mediated changes contribute to axonal swelling under hyperbaric conditions.

To determine whether increased pressure triggers release of ATP, Reigada et al. (2008) [91] loaded air or nitrogen pressure to ex vivo bovine eyecups [91]. One milliliter of buffer solution was added to the bottom of each eyecup and the lid was sealed. Air or nitrogen was injected from a syringe until the pressure reading by digital manometry reached the desired level. When appropriate precautions were taken, pressure levels remained constant throughout the experiment. ATP released from retinal cells diffuses into the vitreous humor. Vitreous humor from each eyecup was collected, and ATP concentrations were determined. Elevated pressure led to an increase in extracellular ATP. This excess extracellular ATP may serve as a link between increased pressure and RGC death in acute glaucoma, suggesting a possible role for ATP in neuronal damage accompanying increased intracranial pressure.

Table 2 is the summarization of characteristics of the experimentally induced in vitro and ex vivo mammalian glaucoma models.

\section{Genetically Modified Mouse Glaucoma Models}

There are numerous mouse models in which glaucoma-like pathology occurs as a result of genetic mutations [43, 92]. A main advantage of these glaucoma models is higher reproducibility of responses following IOP elevations compared to surgically induced models [42]. Because there is significant conservation in mouse and human genomes, the generation of mice with specific mutations identified in human glaucoma can be useful for understanding pathogenesis [43]. We briefly review studies that have utilized genetically modified mouse models to examine the roles of different genes in the glaucoma pathogenesis.

5.1. GLAST and EAAC-1. Normal tension glaucoma (NTG) is a condition in which clinical features are largely identical to those seen in primary open angle glaucoma (POAG) except for the relatively low IOP $(<22 \mathrm{~mm} \mathrm{Hg})$. The pathophysiology of RGC degeneration and optic nerve damage in NTG remains unclear. To explore possible pathways of RGC degeneration, genetically modified mice with normal IOP have been used as models of NTG. Harada et al. [18] showed that mice with deficient expression of the glutamate transporters, GLAST or EAAC-1, demonstrate spontaneous RGC death and optic nerve degeneration without elevated IOP. In GLAST-deficient mice, administration of a glutamate receptor antagonist prevented RGC loss, indicating that GLAST helps to prevent excitotoxic retinal damage. Additionally, GLAST helps to maintain levels of the antioxidant glutathione in Müller cells by transporting glutamate, the substrate for glutathione synthesis, into the cells. Taken together, it appears that GLAST deficiency leads to RGC degeneration by both excitotoxic and oxidative stress mechanisms.

GLAST deficient mice were also used to investigate ASK1 deficiency on RGC death [93]. Apoptosis signalregulating kinase 1 (ASK1) is a mitogen-activated protein kinase (MAPK) that plays an important role in stress-induced RGC apoptosis. Loss of ASK1 had no effects on the production of glutathione or malondialdehyde in the retina or on IOP. Tumor-necrosis-factor (TNF) induced activation of p38 MAPK and production of inducible nitric oxide synthase were also suppressed in ASK1-deficient Müller glial cells and RGCs, suggesting that ASK1 activation is involved in NTG.

5.2. $C Y P 1 B 1$. $C Y P 1 B 1$ is a gene implicated in congenital glaucoma and codes the enzyme, cytochrome P450, family 1 , subfamily b, polypeptide $1[94,95]$. The role that CYP1B1 plays in the pathophysiology of glaucoma and the development of anterior chamber anomalies is not known. Nonetheless, CYP1B1-deficient mice exhibit abnormalities in their aqueous drainage system that are similar to those reported in 
TABLE 2: Experimentally induced in vitro and ex vivo mammalian glaucoma models.

\begin{tabular}{|c|c|c|c|c|c|}
\hline & Species & Main papers & $\begin{array}{l}\text { Pressure } \\
(\mathrm{mm} \mathrm{Hg})\end{array}$ & $\begin{array}{l}\text { Duration } \\
\text { (hours) }\end{array}$ & Main outcomes measured \\
\hline \multicolumn{6}{|l|}{ In vitro glaucoma models } \\
\hline Hydro pressure model & Porcine & Obazawa et al. (2004) [73] & 3,33 & $12,24,48,72$ & $\begin{array}{l}\text { Optineurin and myocilin } \\
\text { expression in trabecular } \\
\text { meshwork cells }\end{array}$ \\
\hline Centrifugation model & Rat & Kashiwagi et al. (2004) [74] & $16,28,33$ & 24,48 & $\begin{array}{l}\text { Expressional changes in mRNA } \\
\text { in RGC and retinal glia }\end{array}$ \\
\hline \multicolumn{6}{|l|}{ Ex vivo glaucoma models } \\
\hline Hydro pressure model & Rat & Ishikawa et al. (2010) [17] & $10,25,50,75$ & 24 & $\begin{array}{l}\text { Histology of the retinal nerve } \\
\text { fiber, Glutamine synthetase } \\
\text { activity }\end{array}$ \\
\hline Gas pressure model & Bovine & Reigada et al. (2008) [91] & $20-100$ & 0.5 & Retinal ATP release \\
\hline
\end{tabular}

human angle-closure glaucoma patients [96]. In contrast, other studies using CYP1B1-null mice revealed no evidence of IOP elevation [97]. Although CYP1B1 knockout mice do not develop elevated IOP, they have abnormalities in their aqueous drainage system, small or absent Schlemm's canal, defects in trabecular meshwork, and peripheral anterior synechia of the iris [97]. A mouse model with mutations in both CYP1B1 and Tyr was also developed and revealed that Tyr mutation modifies the phenotype associated with inheritance of mutant orthologs of CYP1B1 and Foxc1, both of which have been shown to be involved in human angleclosure glaucoma $[96,97]$.

5.3. Alpha-1 Subunit of Collagen Type 1. More recently, a transgenic mouse model of POAG has emerged. This mouse model has a targeted mutation in the gene for the alpha-1 subunit of collagen type 1 and demonstrates progressive loss of RGC axons induced by IOP elevation [98]. Organization of the drainage structures seems normal in this model.

5.4. Myocilin. The myocilin gene (Myoc) encodes a secreted glycoprotein. Tyr437His mutation in Myoc leads to severe glaucoma in humans [99], and the mouse Tyr423His mutation corresponds to this human mutation [100]. Tyr423His Myoc mice demonstrate progressive degenerative changes in the peripheral RGC layer and optic nerve, with normal organization of aqueous drainage structures [101]. It has been suggested that mice expressing mutated mouse or human Myoc in the trabecular meshwork have characteristics of POAG $[101,102]$. By contrast, expression of the mutated Myoc allele (Tyr423His) specifically in the iridocorneal angle does not lead to IOP elevation and does not produce degenerative changes in the retina [103]. These differences might be explained by differences in the levels of mutated Myoc expression as well as by differences in genetic background [103].

\section{Conclusions}

This paper describes animal models used in glaucoma research. These animal models are essential to elucidate the natural course of the disease and to develop novel therapeutic approaches. However, glaucoma is a disorder with complicated pathogenesis that is far from being completely understood. Since the mechanisms of glaucoma differ among animal models, the selection of an animal model should be based on experimental needs and the hypothesis being tested. Experimentally, induced in vivo models have the advantage of studying certain changes in glaucoma in a living animal. However, the duration of IOP elevation in these models is transient without sequential treatments. In addition, precise control over IOP is difficult, and the timing of induction and progression of glaucoma are often unpredictable. While in vivo animal models are necessary to demonstrate that a phenomenon occurs in living organisms, in vivo animal experiments usually include undefined and uncontrollable factors. For this reason, in vitro systems have been useful for conducting highly controlled experiments in specific contexts. In vitro experiments using primary cultures of RGCs are not easy to perform, however, mainly because of the limited cellular yield in adult animals and the typically postmitotic feature of RGCs. Thus, early postnatal tissues are used in order to optimize cell number and survival in culture. It is important to note, however, that there are major differences in cell responses to external stimulation between postnatal and adult cells. In addition, it is difficult to examine the interaction between RGCs and other types of cells such as retinal glia under these conditions. Recently developed ex vivo models for acute glaucoma involve incubating rat retinal segments under hydrostatic pressure at the bottom of a deep cylinder. The ex vivo hydrostatic pressure model excludes the effects of ischemia and allows studying of the direct effects of pressure on the retina. Additionally, this model includes higher degrees of control over experimental variables and better preservation of neuron-neuron and neuron-glial interactions that are possible in dissociated cell preparations. Ex vivo models are limited by the absence of survival factors supplied by blood or axonal transport, and the incubation period is time limited. Going forward, it is likely that genetic models developed to test specific hypotheses will provide valuable information on pathophysiology and potentially lead to the discovery of new therapeutic targets. By using these animal models, we hope to continue to improve glaucoma prevention and treatment. 


\section{Conflict of Interests}

Charles F. Zorumski is a member of the Scientific Advisory Board of Sage Therapeutics. There are no other competing financial interests.

\section{Acknowledgments}

The authors thank Sanae Takaseki and Yoko Hayami for technical support. This work was supported in part by JSPS KAKENHI Grant no. 24592666 to Makoto Ishikawa and by NIH Grants MH077791, MH101874, and AA017413 to Charles F. Zorumski and the Bantly Foundation.

\section{References}

[1] H. A. Quigley, R. W. Nickells, L. A. Kerrigan, M. E. Pease, D. J. Thibault, and D. J. Zack, "Retinal ganglion cell death in experimental glaucoma and after axotomy occurs by apoptosis," Investigative Ophthalmology and Visual Science, vol. 36, no. 5, pp. 774-786, 1995.

[2] Y. Suzuki, A. Iwase, M. Araie et al., "Risk factors for openangle glaucoma in a Japanese population: the Tajimi study," Ophthalmology, vol. 113, no. 9, pp. 1613-1617, 2006.

[3] K. N. Gelatt, R. L. Peiffer Jr., R. M. Gwin, G. G. Gum, and L. W. Williams, "Clinical manifestations of inherited glaucoma in the beagle," Investigative Ophthalmology \& Visual Science, vol. 16, no. 12, pp. 1135-1142, 1977.

[4] A. E. Kolker, R. A. Moses, M. A. Constant, and B. Becker, "The development of glaucoma in rabbits," Investigative Ophthalmology, vol. 2, no. 4, pp. 316-321, 1963.

[5] S. W. John, R. S. Smith, and O. V. Savinov, "Essential iris atrophy, pigment dispersion, and glaucoma in DBA/2J mice," Investigative Ophthalmology \& Visual Science, vol. 39, no. 6, pp. 951-962, 1998.

[6] M. G. Anderson, R. S. Smith, N. L. Hawes et al., "Mutations in genes encoding melanosomal proteins cause pigmentary glaucoma in DBA/2J mice," Nature Genetics, vol. 30, no. 1, pp. 81-85, 2002.

[7] M. G. Anderson, K. S. Nair, L. A. Amonoo et al., "Gpnmb ${ }^{R 150 X}$ allele must be present in bone marrow derived cells to mediate DBA/2J glaucoma," BMC Genetics, vol. 9, article 30, 2008.

[8] E. Vecino and S. C. Sharma, "Glaucoma animal models," in Glaucoma-Basic and Clinical Aspects, S. Rumelt, Ed., pp. 319334, InTech Europe Publisher, Rijeka, Croatia, 2013.

[9] N. H. Kalvin, D. I. Hamasaki, and J. D. Gass, "Experimental glaucoma in monkeys. I. Relationship between intraocular pressure and cupping of the optic disc and cavernous atrophy of the optic nerve," Archives of Ophthalmology, vol. 76, no. 1, pp. 82-93, 1966.

[10] S. Lessell and T. Kuwabara, "Experimental alpha-chymotrypsin glaucoma," Archives of Ophthalmology, vol. 81, no. 6, pp. 853$864,1969$.

[11] D. Gaasterland and C. Kupfer, "Experimental glaucoma in the rhesus monkey," Investigative Ophthalmology, vol. 13, no. 6, pp. 455-457, 1974.

[12] H. A. Quigley and E. M. Addicks, "Chronic experimental glaucoma in primates. I. Production of elevated intraocular pressure by anterior chamber injection of autologous ghost red blood cells," Investigative Ophthalmology and Visual Science, vol. 19, no. 2, pp. 126-136, 1980.
[13] M. V. Fedorchak, I. P. Conner, C. A. Medina, J. B. Wingard, J. S. Schuman, and S. R. Little, "28-day intraocular pressure reduction with a single dose of brimonidine tartrate-loaded microspheres," Experimental Eye Research, vol. 125, pp. 210-216, 2014.

[14] J. C. Morrison, C. G. Moore, L. M. H. Deppmeier, B. G. Gold, C. K. Meshul, and E. C. Johnson, "A rat model of chronic pressureinduced optic nerve damage," Experimental Eye Research, vol. 64, no. 1, pp. 85-96, 1997.

[15] S. R. Shareef, E. Garcia-Valenzuela, A. Salierno, J. Walsh, and S. C. Sharma, "Chronic ocular hypertension following episcleral venous occlusion in rats," Experimental Eye Research, vol. 61, no. 3, pp. 379-382, 1995.

[16] M. B. Wax, G. Tezel, S. Kobayashi, and M. R. Hernandez, "Responses of different cell lines from ocular tissues to elevated hydrostatic pressure," British Journal of Ophthalmology, vol. 84, no. 4, pp. 423-428, 2000.

[17] M. Ishikawa, T. Yoshitomi, C. F. Zorumski, and Y. Izumi, "Effects of acutely elevated hydrostatic pressure in a rat ex vivo retinal preparation," Investigative Ophthalmology and Visual Science, vol. 51, no. 12, pp. 6414-6423, 2010.

[18] T. Harada, C. Harada, K. Nakamura et al., "The potential role of glutamate transporters in the pathogenesis of normal tension glaucoma," The Journal of Clinical Investigation, vol. 117, no. 7, pp. 1763-1770, 2007.

[19] M. Aihara, J. D. Lindsey, and R. N. Weinreb, "Experimental mouse ocular hypertension: establishment of the model," Investigative Ophthalmology and Visual Science, vol. 44, no. 10, pp. 4314-4320, 2003.

[20] F. Mabuchi, M. Aihara, M. R. Mackey, J. D. Lindsey, and R. N. Weinreb, "Optic nerve damage in experimental mouse ocular hypertension," Investigative Ophthalmology and Visual Science, vol. 44, no. 10, pp. 4321-4330, 2003.

[21] E. van der Zypen, "Experimental morphological study on structure and function of the filtration angle of the rat eye," Ophthalmologica, vol. 174, no. 5, pp. 285-298, 1977.

[22] T. Gherezghiher, W. F. March, R. E. Nordquist, and M. C. Koss, "Laser-induced glaucoma in rabbits," Experimental Eye Research, vol. 43, no. 6, pp. 885-894, 1986.

[23] B. Johnson, P. House, W. Morgan, X. Sun, and D.-Y. Yu, "Developing laser-induced glaucoma in rabbits," Australian and New Zealand Journal of Ophthalmology, vol. 27, no. 3-4, pp. 180183, 1999.

[24] R. J. Seidehamel and K. W. Dungan, "Characteristics and pharmacologic utility of an intraocular pressure (IOP) model in unanesthetized rabbits," Investigative Ophthalmology, vol. 13, no. 4, pp. 319-322, 1974.

[25] H. A. Quigley, R. M. Sanchez, G. R. Dunkelberger, N. L. L'Hernault, and T. A. Baginski, "Chronic glaucoma selectively damages large optic nerve fibers," Investigative Ophthalmology and Visual Science, vol. 28, no. 6, pp. 913-920, 1987.

[26] Y. Glovinsky, H. A. Quigley, and G. R. Dunkelberger, "Retinal ganglion cell loss is size dependent in experimental glaucoma," Investigative Ophthalmology \& Visual Science, vol. 32, no. 3, pp. 484-491, 1991.

[27] Y. Glovinsky, H. A. Quigley, and M. E. Pease, "Foveal ganglion cell loss is size dependent in experimental glaucoma," Investigative Ophthalmology \& Visual Science, vol. 34, no. 2, pp. 395-400, 1993.

[28] H. A. Quigley and R. M. Hahman, "Laser energy levels for trabecular meshwork damage in the primate eye," Investigative 
Ophthalmology and Visual Science, vol. 24, no. 9, pp. 1305-1307, 1983.

[29] C. B. Toris, G.-L. Zhan, Y.-L. Wang et al., "Aqueous humor dynamics in monkeys with laser-induced glaucoma," Journal of Ocular Pharmacology and Therapeutics, vol. 16, no. 1, pp. 19-27, 2000.

[30] J. Ruiz-Ederra, M. García, F. Martín et al., "Comparison of three methods of inducing chronic elevation of intraocular pressure in the pig experimental glaucoma," Archivos de la Sociedad Española de Oftalmología., vol. 80, no. 10, pp. 571-579, 2005.

[31] J. Ruiz-Ederra, M. García, M. Hernández et al., "The pig eye as a novel model of glaucoma," Experimental Eye Research, vol. 81, no. 5, pp. 561-569, 2005.

[32] R. A. Bouhenni, J. Dunmire, A. Sewell, and D. P. Edward, "Animal models of glaucoma," Journal of Biomedicine and Biotechnology, vol. 2012, Article ID 692609, 11 pages, 2012.

[33] R. L. Gross, J. Ji, P. Chang et al., "A mouse model of elevated intraocular pressure: retina and optic nerve findings," Transactions of the American Ophthalmological Society, vol. 101, pp. 163$171,2003$.

[34] J. Ji, P. Chang, M. E. Pennesi et al., "Effects of elevated intraocular pressure on mouse retinal ganglion cells," Vision Research, vol. 45, no. 2, pp. 169-179, 2005.

[35] C. T. Fu and D. Sretavan, "Laser-induced ocular hypertension in albino CD-1 mice," Investigative Ophthalmology \& Visual Science, vol. 51, no. 2, pp. 980-990, 2010.

[36] J. Kipnis, E. Yoles, H. Schori, E. Hauben, I. Shaked, and M. Schwartz, "Neuronal survival after CNS insult is determined by a genetically encoded autoimmune response," The Journal of Neuroscience, vol. 21, no. 13, pp. 4564-4571, 2001.

[37] T. Daimon, M. Kazama, Y. Miyajima, and M. Nakano, "Immunocytochemical localization of thrombomodulin in the aqueous humor passage of the rat eye," Histochemistry and Cell Biology, vol. 108, no. 2, pp. 121-131, 1997.

[38] C. Remé, B. Aeberhard, and U. Urner, "The development of the chamber angle in the rat eye. Morphological characteristics of developmental stages," Graefe's Archive for Clinical and Experimental Ophthalmology, vol. 220, no. 3, pp. 139-153, 1983.

[39] P. Nucci, G. Tredici, M. P. Manitto, G. Pizzini, and R. Brancato, "Neuron-specific enolase and embryology of the trabecular meshwork of the rat eye: an immunohistochemical study," International Journal of Biological Markers, vol. 7, no. 4, pp. 253255, 1992.

[40] I.-H. Pang, W.-H. Wang, and A. F. Clark, "Acute effects of glaucoma medications on rat intraocular pressure," Experimental Eye Research, vol. 80, no. 2, pp. 207-214, 2005.

[41] J. Ueda, S. Sawaguchi, T. Hanyu et al., "Experimental glaucoma model in the rat induced by laser trabecular photocoagulation after an intracameral injection of india ink," Japanese Journal of Ophthalmology, vol. 42, no. 5, pp. 337-344, 1998.

[42] H. Levkovitch-Verbin, H. A. Quigley, K. R. G. Martin, D. Valenta, L. A. Baumrind, and M. E. Pease, "Translimbal laser photocoagulation to the trabecular meshwork as a model of glaucoma in rats," Investigative Ophthalmology and Visual Science, vol. 43, no. 2, pp. 402-410, 2002.

[43] T. V. Johnson and S. I. Tomarev, "Rodent models of glaucoma," Brain Research Bulletin, vol. 81, no. 2-3, pp. 349-358, 2010.

[44] M. R. Steinhart, F. E. Cone, C. Nguyen et al., "Mice with an induced mutation in collagen 8A2 develop larger eyes and are resistant to retinal ganglion cell damage in an experimental glaucoma model," Molecular Vision, vol. 18, pp. 1093-1106, 2012.
[45] Y. You, V. K. Gupta, J. C. Li, N. Al-Adawy, A. Klistorner, and S. L. Graham, "FTY720 protects retinal ganglion cells in experimental glaucoma," Investigative Ophthalmology and Visual Science, vol. 55, no. 5, pp. 3060-3066, 2014.

[46] Q. C. Ngumah, S. D. Buchthal, and R. F. Dacheux, "Longitudinal non-invasive proton NMR spectroscopy measurement of vitreous lactate in a rabbit model of ocular hypertension," Experimental Eye Research, vol. 83, no. 2, pp. 390-400, 2006.

[47] H. A. Quigley and E. M. Addicks, "Chronic experimental glaucoma in primates. II. Effect of extended intraocular pressure elevation on optic nerve head and axonal transport," Investigative Ophthalmology and Visual Science, vol. 19, no. 2, pp. 137-152, 1980.

[48] A. J. Weber and D. Zelenak, "Experimental glaucoma in the primate induced by latex microspheres," Journal of Neuroscience Methods, vol. 111, no. 1, pp. 39-48, 2001.

[49] R. M. Sappington, B. J. Carlson, S. D. Crish, and D. J. Calkins, "The microbead occlusion model: a paradigm for induced ocular hypertension in rats and mice," Investigative Ophthalmology \& Visual Science, vol. 51, no. 1, pp. 207-216, 2010.

[50] F. E. Cone, M. R. Steinhart, E. N. Oglesby, G. Kalesnykas, M. E. Pease, and H. A. Quigley, "The effects of anesthesia, mouse strain and age on intraocular pressure and an improved murine model of experimental glaucoma," Experimental Eye Research, vol. 99, no. 1, pp. 27-35, 2012.

[51] M. C. Moreno, H. J. A. Marcos, J. O. Croxatto et al., "A new experimental model of glaucoma in rats through intracameral injections of hyaluronic acid," Experimental Eye Research, vol. 81, no. 1, pp. 71-80, 2005.

[52] P. A. Samsel, L. Kisiswa, J. T. Erichsen, S. D. Cross, and J. E. Morgan, "A novel method for the induction of experimental glaucoma using magnetic microspheres," Investigative Ophthalmology and Visual Science, vol. 52, no. 3, pp. 1671-1675, 2011.

[53] S. Yu, T. Tanabe, and N. Yoshimura, "A rat model of glaucoma induced by episcleral vein ligation," Experimental Eye Research, vol. 83, no. 4, pp. 758-770, 2006.

[54] J. Ruiz-Ederra and A. S. Verkman, "Mouse model of sustained elevation in intraocular pressure produced by episcleral vein occlusion," Experimental Eye Research, vol. 82, no. 5, pp. 879884, 2006.

[55] C. T. Fu and D. Sretavan, "Laser-induced ocular hypertension in albino CD-1 mice," Investigative Ophthalmology and Visual Science, vol. 51, no. 2, pp. 980-990, 2010.

[56] R. L. Gross, J. Ji, P. Chang et al., "A mouse model of elevated intraocular pressure: retina and optic nerve findings," Transactions of the American Ophthalmological Society, vol. 101, pp. 163171, 2003.

[57] E. Vecino and S. C. Sharma, "Glaucoma animal models," in Glaucoma-Basic and Clinical Aspects, S. Rumelt, Ed., pp. 319334, InTech Europe, Rijeka, Croatia, 2013.

[58] J. H. Urcola, M. Hernández, and E. Vecino, “Three experimental glaucoma models in rats: comparison of the effects of intraocular pressure elevation on retinal ganglion cell size and death," Experimental Eye Research, vol. 83, no. 2, pp. 429-437, 2006.

[59] A. Kipfer-Kauer, S. J. McKinnon, B. E. Frueh, and D. Goldblum, "Distribution of amyloid precursor protein and amyloid- $\beta$ in ocular hypertensive C57BL/6 mouse eyes," Current Eye Research, vol. 35, no. 9, pp. 828-834, 2010.

[60] M. Rudzinski and H. U. Saragovi, "Glaucoma: validated and facile in vivo experimental models of a chronic neurodegenerative disease for drug development," Current Medicinal 
Chemistry-Central Nervous System Agents, vol. 5, no. 1, pp. 4349, 2005.

[61] Y. Lei, S. Rajabi, R. M. Pedrigi, D. R. Overby, A. Thomas Read, and C. Ross Ethier, "In vitro models for glaucoma research: effects of hydrostatic pressure," Investigative Ophthalmology and Visual Science, vol. 52, no. 9, pp. 6329-6339, 2011.

[62] A. Agar, S. Li, N. Agarwal, M. T. Coroneo, and M. A. Hill, "Retinal ganglion cell line apoptosis induced by hydrostatic pressure," Brain Research, vol. 1086, no. 1, pp. 191-200, 2006.

[63] M. Salvador-Silva, S. Aoi, A. Parker, P. Yang, P. Pecen, and M. R. Hernandez, "Responses and signaling pathways in human optic nerve head astrocytes exposed to hydrostatic pressure in vitro," Glia, vol. 45, no. 4, pp. 364-377, 2004.

[64] A. Agar, S. S. Yip, M. A. Hill, and M. T. Coroneo, "Pressure related apoptosis in neuronal cell lines," Journal of Neuroscience Research, vol. 60, no. 4, pp. 495-503, 2000.

[65] Q. Liu, W.-K. Ju, J. G. Crowston et al., "Oxidative stress is an early event in hydrostatic pressure-induced retinal ganglion cell damage," Investigative Ophthalmology \& Visual Science, vol. 48, no. 10, pp. 4580-4589, 2007.

[66] G. Tezel and M. B. Wax, "Increased production of tumor necrosis factor- $\alpha$ by glial cells exposed to simulated ischemia or elevated hydrostatic pressure induces apoptosis in cocultured retinal ganglion cells," The Journal of Neuroscience, vol. 20, no. 23, pp. 8693-8700, 2000.

[67] W.-K. Ju, Q. Liu, K.-Y. Kim et al., "Elevated hydrostatic pressure triggers mitochondrial fission and decreases cellular ATP in differentiated RGC-5 cells," Investigative Ophthalmology \& Visual Science, vol. 48, no. 5, pp. 2145-2151, 2007.

[68] M. R. Hernandez, J. D. Pena, J. A. Selvidge, M. SalvadorSilva, and P. Yang, "Hydrostatic pressure stimulates synthesis of elastin in cultured optic nerve head astrocytes," Glia, vol. 32, no. 2, p. 122, 2000.

[69] C. S. Ricard, S. Kobayashi, J. D. O. Pena, M. Salvador-Silva, O. Agapova, and M. R. Hernandez, "Selective expression of neural cell adhesion molecule (NCAM)-180 in optic nerve head astrocytes exposed to elevated hydrostatic pressure in vitro," Molecular Brain Research, vol. 81, no. 1-2, pp. 62-79, 2000.

[70] B. Liu and A. H. Neufeld, "Nitric oxide synthase-2 in human optic nerve head astrocytes induced by elevated pressure in vitro," Archives of Ophthalmology, vol. 119, no. 2, pp. 240-245, 2001.

[71] J. L. Yang, A. H. Neufeld, M. B. Zorn, and M. R. Hernandez, "Collagen type I mRNA levels in cultured human lamina cribrosa cells: effects of elevated hydrostatic pressure," Experimental Eye Research, vol. 56, no. 5, pp. 567-574, 1993.

[72] P. Yang, O. Agapova, A. Parker et al., "DNA microarray analysis of gene expression in human optic nerve head astrocytes in response to hydrostatic pressure," Physiological Genomics, vol. 17, no. 2, pp. 157-169, 2004.

[73] M. Obazawa, Y. Mashima, N. Sanuki et al., "Analysis of porcine optineurin and myocilin expression in trabecular meshwork cells and astrocytes from optic nerve head," Investigative Ophthalmology and Visual Science, vol. 45, no. 8, pp. 2652-2659, 2004.

[74] K. Kashiwagi, Y. Iizuka, Y. Tanaka, M. Araie, Y. Suzuki, and S. Tsukahara, "Molecular and cellular reactions of retinal ganglion cells and retinal glial cells under centrifugal force loading," Investigative Ophthalmology and Visual Science, vol. 45, no. 10, pp. 3778-3786, 2004.
[75] J. Yu, Y. Zhong, Y. Cheng, X. Shen, J. Wang, and Y. Wei, "Effect of high hydrostatic pressure on the expression of glutamine synthetase in rat retinal Müller cells cultured in vitro," Experimental and Therapeutic Medicine, vol. 2, no. 3, pp. 513-516, 2011.

[76] S. J. McKinnon, D. M. Lehman, L. A. Kerrigan-Baumrind et al., "Caspase activation and amyloid precursor protein cleavage in rat ocular hypertension," Investigative Ophthalmology \& Visual Science, vol. 43, no. 4, pp. 1077-1087, 2002.

[77] G. Tezel and M. B. Wax, "The mechanisms of hsp27 antibodymediated apoptosis in retinal neuronal cells," Journal of Neuroscience, vol. 20, no. 10, pp. 3552-3562, 2000.

[78] G. Tezel and M. B. Wax, "Inhibition of caspase activity in retinal cell apoptosis induced by various stimuli in vitro," Investigative Ophthalmology \& Visual Science, vol. 40, no. 11, pp. 2660-2667, 1999.

[79] G. Tezel and X. Yang, "Caspase-independent component of retinal ganglion cell death, in vitro," Investigative Ophthalmology and Visual Science, vol. 45, no. 11, pp. 4049-4059, 2004.

[80] T. V. Johnson and S. I. Tomarev, "Rodent models of glaucoma," Brain Research Bulletin, vol. 81, no. 2-3, pp. 349-358, 2010.

[81] S. W. Park, K.-Y. Kim, J. D. Lindsey et al., "A selective inhibitor of Drp1, Mdivi-1, increases retinal ganglion cell survival in acute ischemic mouse retina," Investigative Ophthalmology \& Visual Science, vol. 52, no. 5, pp. 2837-2843, 2011.

[82] S. Yoneda, E. Tanaka, W. Goto, T. Ota, and H. Hara, “Topiramate reduces excitotoxic and ischemic injury in the rat retina," Brain Research, vol. 967, no. 1-2, pp. 257-266, 2003.

[83] M. Ishikawa, T. Yoshitomi, C. F. Zorumski, and Y. Izumi, "Downregulation of glutamine synthetase via GLAST suppression induces retinal axonal swelling in a rat ex vivo hydrostatic pressure model," Investigative Ophthalmology \& Visual Science, vol. 52, no. 9, pp. 6604-6616, 2011.

[84] Y. Izumi, A. M. Benz, C. O. Kirby et al., "An ex vivo rat retinal preparation for excitotoxicity studies," Journal of Neuroscience Methods, vol. 60, no. 1-2, pp. 219-225, 1995.

[85] J. W. Olney, T. Fuller, and T. de Gubareff, "Acute dendrotoxic changes in the hippocampus of kainate treated rats," Brain Research, vol. 176, no. 1, pp. 91-100, 1979.

[86] R. S. Sloviter and D. W. Dempster, “'Epileptic' brain damage is replicated qualitatively in the rat hippocampus by central injection of glutamate or aspartate but not by GABA or acetylcholine," Brain Research Bulletin, vol. 15, no. 1, pp. 39-60, 1985.

[87] F. Dessi, C. Charriaut-Marlangue, and Y. Ben-Ari, "Glutamateinduced neuronal death in cerebellar culture is mediated by two distinct components: a sodium-chloride component and a calcium component," Brain Research, vol. 650, no. 1, pp. 49-55, 1994.

[88] C. Peterson, J. H. Neal, and C. W. Cotman, "Development of $N$-methyl-d-aspartate excitotoxicity in cultured hippocampal neurons," Developmental Brain Research, vol. 48, no. 2, pp. 187195, 1989.

[89] J. E. Friedman and G. G. Haddad, "Major differences in $\mathrm{Ca}_{i}^{2+}$ response to anoxia between neonatal and adult rat CA1 neurons: role of $\mathrm{Ca}_{o}^{2+}$ and $\mathrm{Na}_{o}^{+}$, The Journal of Neuroscience, vol. 13, no. 1, pp. 63-72, 1993.

[90] S. M. Rothman, "The neurotoxicity of excitatory amino acids is produced by passive chloride influx," Journal of Neuroscience, vol. 5, no. 6, pp. 1483-1489, 1985.

[91] D. Reigada, W. Lu, M. Zhang, and C. H. Mitchell, "Elevated pressure triggers a physiological release of ATP from the retina: 
possible role for pannexin hemichannels," Neuroscience, vol. 157, no. 2, pp. 396-404, 2008.

[92] S. J. McKinnon, C. L. Schlamp, and R. W. Nickells, "Mouse models of retinal ganglion cell death and glaucoma," Experimental Eye Research, vol. 88, no. 4, pp. 816-824, 2009.

[93] C. Harada, K. Namekata, X. Guo et al., "ASK1 deficiency attenuates neural cell death in GLAST-deficient mice, a model of normal tension glaucoma," Cell Death \& Differentiation, vol. 17, no. 11, pp. 1751-1759, 2010.

[94] B. A. Bejjani, R. A. Lewis, K. F. Tomey et al., "Mutations in CYP1B1, the gene for cytochrome P4501B1, are the predominant cause of primary congenital glaucoma in Saudi Arabia," American Journal of Human Genetics, vol. 62, no. 2, pp. 325-333, 1998.

[95] M. Sarfarazi and I. Stoilov, "Molecular genetics of primary congenital glaucoma," Eye, vol. 14, no. 3, pp. 422-428, 2000.

[96] J. T. M. Buters, S. Sakai, T. Richter et al., "Cytochrome p450 CYP1B1 determines susceptibility to 7,12-dimethylbenz[a]anthracene-induced lymphomas," Proceedings of the National Academy of Sciences of the United States of America, vol. 96, no. 5, pp. 1977-1982, 1999.

[97] R. T. Libby, R. S. Smith, O. V. Savinova et al., "Modification of ocular defects in mouse developmental glaucoma models by tyrosinase," Science, vol. 299, no. 5612, pp. 1578-1581, 2003.

[98] F. Mabuchi, J. D. Lindsey, M. Aihara, M. R. Mackey, and R. N. Weinreb, "Optic nerve damage in mice with a targeted type I collage mutation," Investigative Ophthalmology and Visual Science, vol. 45, no. 6, pp. 1841-1845, 2004.

[99] W. L. M. Alward, J. H. Fingert, M. A. Coote et al., "Clinical features associated with mutations in the chromosome 1 openangle glaucoma gene (GLC1A)," The New England Journal of Medicine, vol. 338, no. 15, pp. 1022-1027, 1998.

[100] I. Malyukova, H.-S. Lee, R. N. Fariss, and S. I. Tomarev, "Mutated mouse and human myocilins have similar properties and do not block general secretory pathway," Investigative Ophthalmology and Visual Science, vol. 47, no. 1, pp. 206-212, 2006.

[101] Y. Zhou, O. Grinchuk, and S. I. Tomarev, “Transgenic mice expressing the Tyr437His mutant of human myocilin protein develop glaucoma," Investigative Ophthalmology and Visual Science, vol. 49, no. 5, pp. 1932-1939, 2008.

[102] V. Senatorov, I. Malyukova, R. Fariss et al., "Expression of mutated mouse myocilin induces open-angle glaucoma in transgenic mice," The Journal of Neuroscience, vol. 26, no. 46, pp. 11903-11914, 2006.

[103] D. B. Gould, M. Reedy, L. A. Wilson, R. S. Smith, R. L. Johnson, and S. W. M. John, "Mutant myocilin nonsecretion in vivo is not sufficient to cause glaucoma," Molecular and Cellular Biology, vol. 26, no. 22, pp. 8427-8436, 2006. 


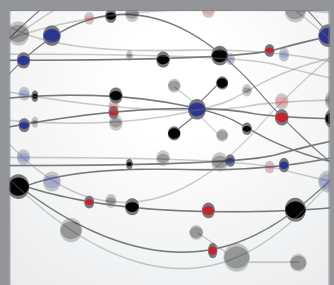

The Scientific World Journal
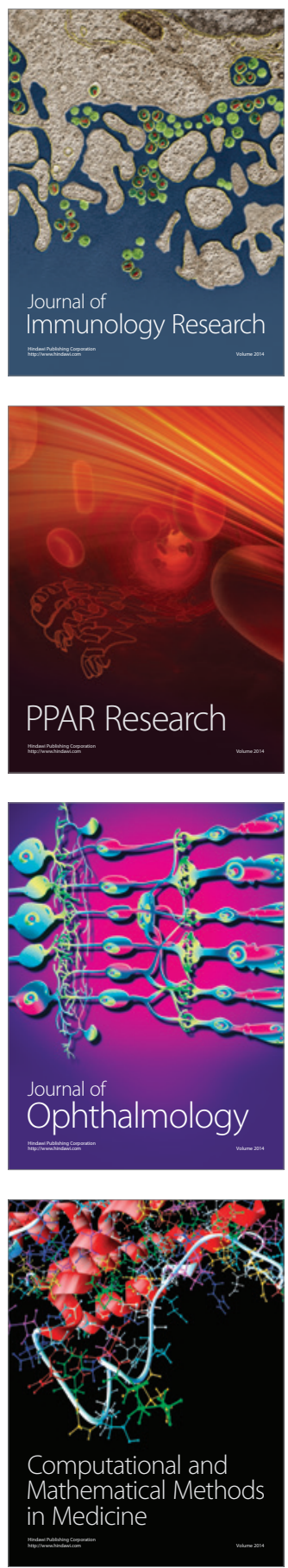

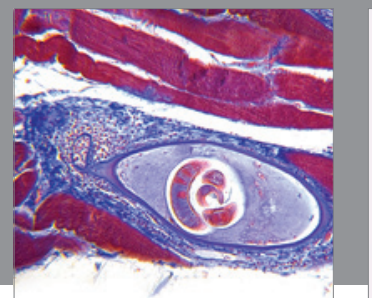

Gastroenterology

Research and Practice
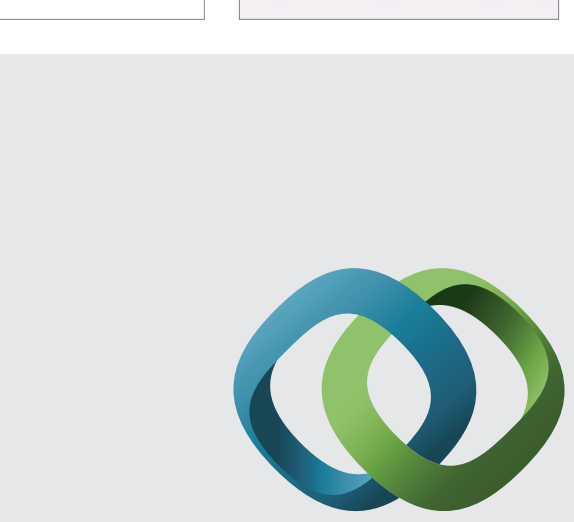

\section{Hindawi}

Submit your manuscripts at

http://www.hindawi.com
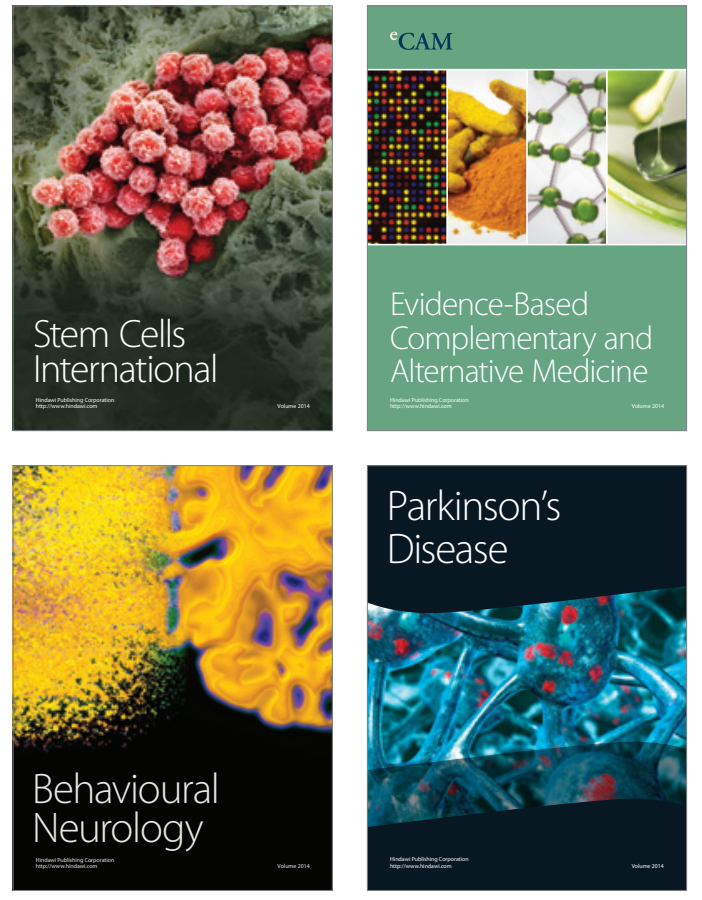
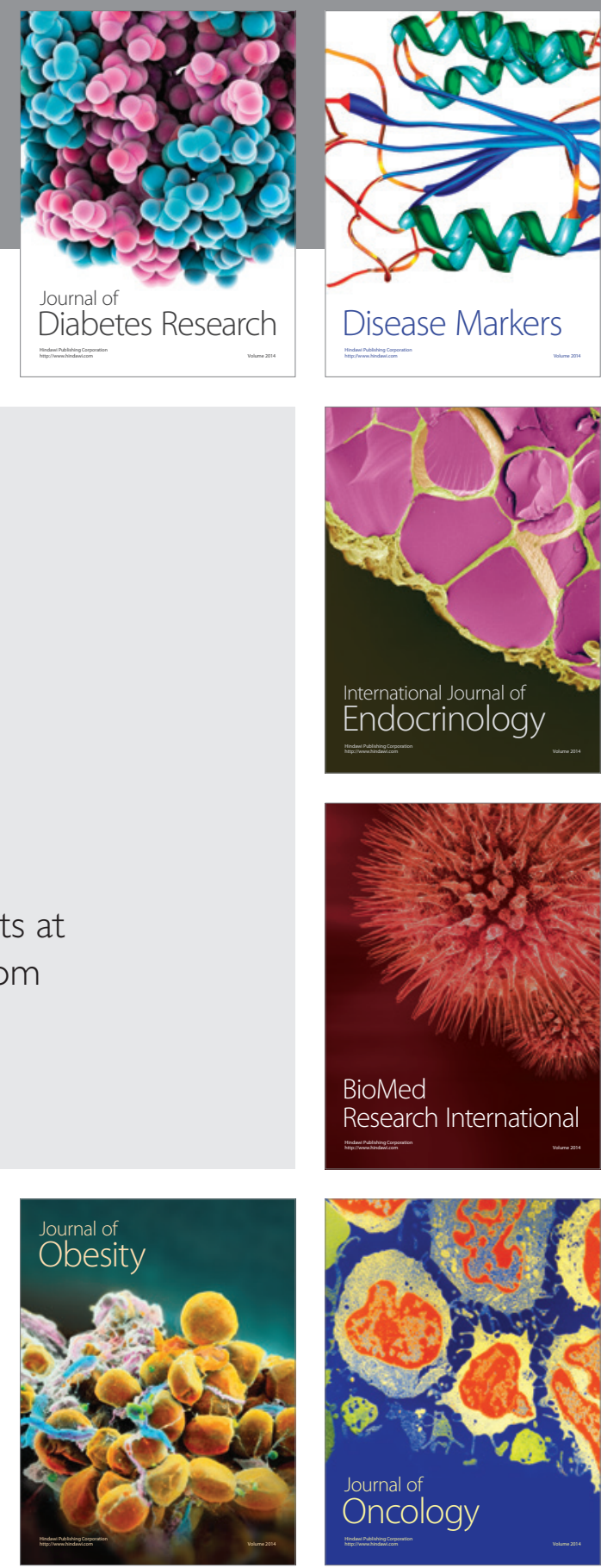

Disease Markers
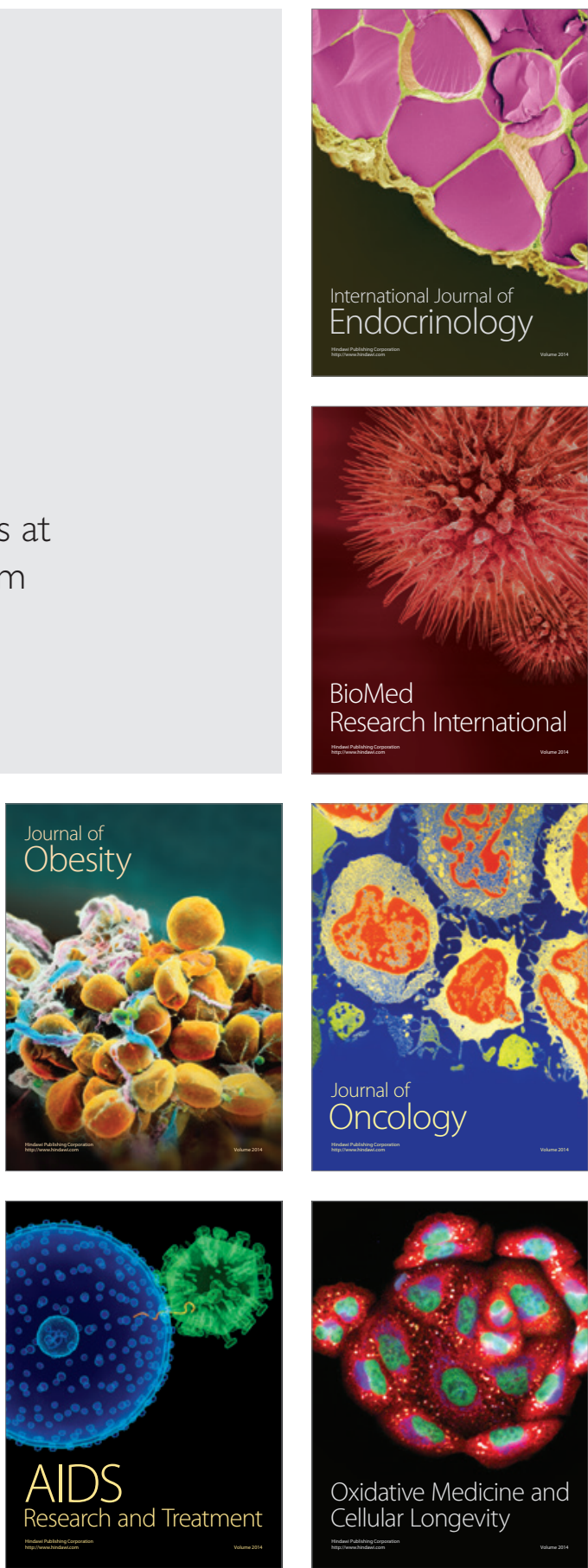